Article

\title{
Knowledge-Perception Bridge of Green-Smart Integration of Cities: An Empirical Study of Hong Kong
}

\author{
Chung-Shing Chan * and Lawal M. Marafa \\ Department of Geography and Resource Management, The Chinese University of Hong Kong, Shatin, N.T., \\ Hong Kong, China; lmmarafa@cuhk.edu.hk \\ * Correspondence: ccs_johnson@cuhk.edu.hk
}

Received: 30 November 2017; Accepted: 28 December 2017; Published: 4 January 2018

\begin{abstract}
Cities often thematize themselves as attractive and sustainable places by adopting some emerging concepts of urban development. Green city and smart city are two of these themes that contain distinctive but often overlapping attributes. These green and smart city attributes, as proposed in previous studies, are tested with a sample of Hong Kong residents $(n=243)$. This paper identifies the factors in a combined green-smart theme of Hong Kong based on local perception. The empirical results confirm that local residents believe Hong Kong is performing smarter than greener. The findings from factor analysis reveal a combined green-smart structure consisting of one mixed green-smart infrastructural elements and six other specific factors about greenness or smartness. Regression also builds up two models showing the locally-perceived determinants of a successful green city and smart city for Hong Kong, respectively. This study reflects a complexity-simplicity paradox of how decision makers should respond to a knowledge-perception gap. The result further confirms that human factor, including the engagement and the quality of societal actors, is the key to successful green and smart urban development.
\end{abstract}

Keywords: city thematization; green city; knowledge-perception gap; smart city; sustainable urban development

\section{Introduction}

Cities often develop themes of characteristics, features or development areas [1], which may be framed within the creation of a unique cultural setting and urban development (e.g., a green city, a smart city, a creative city, and a sustainable city). Some of these themes are constructed and transferred to a value-promised and value-laden marketing concept and even city brand although there often exists questionable compatibility and a strong tension between the quest for diversity and the desire for distinctiveness [2,3]. Across a great variety of city themes, two of them stand out to be more relevant and interconnected to urban sustainability: green city [4] and smart city [5,6], although the two concepts emerged and evolved in separate eras of urban development [7-11].

There are numerous scholarly discussions and empirical studies that have shown an overlap and an integration of "green" and "smart" in various aspects of city development [12,13], especially in the context of energy supply and consumption (e.g., [14]) or other innovative uses of technology (e.g., [15-18]). These initiatives were all connected to the vision of sustainable development in cities [6,11].

The knowledge and research areas in urban green movement and smart urban development have fit well into the needs of the modern society $[19,20]$. However, there is a lack of understanding of how the theoretical knowledge about green city and smart city is being perceived and interpreted by some important groups of city users, such as local residents. Local residents play indispensable role in contributing many aspects of development such as tourist destinations [21,22], 
urban governance [23,24], and co-creating the image of a city to outsiders [25,26]. Two issues have arguably created obstacles to achieving a truly successful and practical green city and smart city. Firstly, a noticeable disparity may appear between the expert-led decision and the multiple stakeholder-based urban governance process. "What is 'good practice', cannot a priori be established by prioritizing one type of knowledge but may be the outcome of a process of multiple actors" [27]. Secondly, an urban development paradigm may turn to a promising theme to attract potential immigrants only when the city marketers and governments properly understand and match the expectations of the target recipients [28], which were not often the case [29]. Some of the underlying elements of green and smart urbanism, for example greenery and utility infrastructure, may be more visible and have stronger power to catch the public attention, which may in turn become the positive attributes for city marketing and development.

These two problems must be addressed by bridging the knowledge gaps between theory and practice in both the discussions about green and smart governance [30]. It is essential to learn about how the theoretical trajectories of green and smart cities demonstrate "some degree of overlap and cross-fertilization" [31], especially from the local perspective [32]. From a policy-supporting angle, a study about the local perception of a green city and a smart city, and their underlying aspects should be a conscientious and bottom-up scrutiny of the policy direction of a city government. This will provide policy-makers with a useful reference on the public feedback of the city's development path. Given a theoretical overlap of many of the city themes [31], there is in principle the possibility of a less rigid but an integrated form of city theme. A strong city thematization must not be directed from the policy-makers and urban planners, but should consider and involve the support from the target city users and residents, as what was suggested as the notion of "going-global and staying local" proposed by Chang [33,34].

This paper presents the study of Hong Kong, where the government has directed Hong Kong to follow and evolve in a range of themes over the past decade, including the ideas of achieving a green city, a creative economy, a digital city and relatively recently, a smart city. These city themes took several forms in the Policy Addresses through, for example, the accumulation of creative capital, the development of cultural and creative industries, and the emergence of creative tourism.

This study selects two interrelated themes of green city and smart city [20], and investigates the local perception of Hong Kong as a green city and a smart city. Two separate lists of green city and smart city attributes are reviewed and collected from the literature, which are presented to a sample of Hong Kong residents for rating and comments. This paper addresses two objectives: (1) to identify the factors in a combined green-smart city theme of Hong Kong as associated by local residents; and (2) to model the relationship between the performance of green-smart city attributes and a locally recognized green-smart city theme for Hong Kong. The resultant model may reveal the construct of and factors leading to a successful green-smart city as believed by Hong Kong residents. The findings of the study allow empirically-based policy recommendations to reach decision-makers for co-creating and legitimizing a strong green and smart city brand.

\section{Characterization of Green and Smart Aspects}

Depending on the strategic areas of focus in each city, the aspects of "green" and "smart" are two popular themes of urban development nowadays [35]. These themes contribute to certain extent of attractiveness to potential immigrants of a city. From the perspective of urban development path, each of these themes is a broad developmental frame that contains its own attributes or aspects of concern, such as energy, waste, food supply, environmental quality, and governance, among others $[20,36]$. These aspects have constituted their own area of research vigorously (e.g., [7,14-18,37]), but the accumulation of knowledge mainly brought about practice and policy discussions from an expert-led and top-down understanding of the areas of interests in green city and smart city, respectively. There is yet an exploratory study on how people perceive and interpret the underlying attributes of these city themes together. This is especially critical for local residents because they are the 
resource users and impact recipients of urban governance. There tends to be a knowledge-perception gap regarding how local residents interpret green city and smart city separately, as well as how these two themes may integrate in the local perception.

In many examples, a specific theme that the decision and policy makers directed to follow may be constructed upon some characteristics believed to be strong or positive by these decision makers [2,38]. The investment in infrastructure for a well-established theme may demand a huge amount of resources. These costs do not necessarily generate public satisfaction, long-term economic and socio-cultural benefits, and ultimately the sustainability of urban development $[20,33,39,40]$. The compatibility of a top-down assigned theme and urban development could sometimes be questioned. A pure focus on economic sustainability may override other important aspects such as socio-cultural concern and quality of local residents [3,40-43]. The selection of greenness and smartness tends to be more appropriate to match the expectation of sustainable development goals of a city [19,43]. Improvement in the participatory and inclusive nature of urban planning and management is especially highlighted by the United Nations [44].

\subsection{Green City and Smart City}

The concepts of green city and smart city did not emerge as two different forms of urban planning or development, but were rather considered as two related paradigms appeared in stages of sustainable development [34]. During the past decades, even long before the emergence of the sustainable development concept, the green city idea had started as a series of new realities of urban life [45]. The green city concept then flourished and evolved across environmental and sustainability movement (e.g., [36,46]), and is generally accepted as a city development that has attained or is moving towards long-term environmental sustainability [47]. One widely adopted definition of green cities defined the concept as those cities that are environmentally friendly [37], and, in connection, embrace aspects including disease control and the public health implications, chemical and physical hazard reduction, high quality urban environments, minimization of urban-rural transfers of environmental costs, and sustainable consumption [37]. Kahn [48] reviewed three approaches to measure urban environmental quality of a "green city", including ecological footprint approach (which translates resources consumption and waste production into the land and water area required to support this level of activity), public health approach (which judges a city according to its environmentally related health problems over time), and compensating differentials approach (which measures differences in urban quality of life by housing price change across cities).

Growing literature on green cities pointed to holistic approaches to urban development that link non-economic aspects (e.g., environmental, health, learning, and community building) with the economic aspects of urban development [39,42,43,49-51]. Over the years, there were many philosophical dialogues and empirical studies that contributed to the theory and practice of green city development, and subsequently evolved paradigms such as eco-, resilient and sustainable city (e.g., [34,36,47,52-54]). Green city movement, research and discussions have covered a series of aspects, as reviewed in Table 1.

Table 1. Aspects of green city research and discussions.

\begin{tabular}{lll}
\hline Green City Aspect & Source \\
\hline 1. & Air quality & $\begin{array}{l}\text { Newman and Kenworthy (1999); Kahn (2006); Roberts, Ravetz, } \\
\text { and George (2009); EIU (2011); Hammer, Kamal-Chaoui, } \\
\text { Robert and Plouin (2011); White (2011); Beatley (2000, 2012); EC (2017) }\end{array}$ \\
\hline 2. & Water quality & $\begin{array}{l}\text { Roley (1992); Newman and Kenworthy (1999); Kahn (2006); Roberts et al. (2009); } \\
\text { EIU (2011); Hammer et al. (2011); Head and Lam (2011); White (2011); } \\
\text { Beatley (2000, 2012); OECD (2014); EC (2017) }\end{array}$ \\
\hline 3. & $\begin{array}{l}\text { Food production by } \\
\text { urban agriculture }\end{array}$ & White (2011); Beatley (2000, 2012) \\
\hline
\end{tabular}


Table 1. Cont.

\begin{tabular}{|c|c|}
\hline Green City Aspect & Source \\
\hline Public transportation & $\begin{array}{l}\text { Siembab and Walter (1992); Snyder (1992); Woodhill (1992); } \\
\text { Newman and Kenworthy (1999); Devuyst (2001); Head and Lam (2011); } \\
\text { Low et al. (2005); Kahn (2006); Kenworthy (2006); Roberts et al. (2009); } \\
\text { EIU (2011); Hammer et al. (2011); White (2011); Beatley (2000, 2012); } \\
\text { OECD (2014); Roumboutsos, Kapros and Vanelslander (2014); EC (2017) }\end{array}$ \\
\hline $\begin{array}{l}\text { Architecture and buildings, } \\
\text { and urban } \\
\text { acoustic environment }\end{array}$ & $\begin{array}{l}\text { Roseland (2001); Low et al. (2005); EIU (2011); Hammer et al. (2011); } \\
\text { Head and Lam (2011); Lehmann (2011); White (2011); Beatley (2000, 2012); } \\
\text { OECD (2014); Rehan (2016) }\end{array}$ \\
\hline Parks and green spaces & $\begin{array}{l}\text { Lipkis (1992); Newman and Kenworthy (1999); Low et al. (2005); Kahn (2006); } \\
\text { Newman (2010); Beatley (2000, 2012); EC (2017) }\end{array}$ \\
\hline Biodiversity & Newman and Kenworthy (1999); Low et al. (2005); Beatley (2000, 2012); EC (2017) \\
\hline $\begin{array}{l}\text { 8. Overall city governance, } \\
\text { equity and participation }\end{array}$ & $\begin{array}{l}\text { Devuyst (2001); Roseland (2001); Low et al. (2005); Roberts et al. (2009); } \\
\text { EIU (2011); Beatley (2000, 2012); De Jong, Wang and Yu (2013); } \\
\text { Meijering, Kern and Tobi (2014); University of Washington (2016); EC (2017) }\end{array}$ \\
\hline Waste management & $\begin{array}{l}\text { Clements (1992); Westley (1992); Newman and Kenworthy (1999); Devuyst (2001); } \\
\text { Kahn (2006); Roberts et al. (2009); EIU (2011); Hammer et al. (2011); } \\
\text { Head and Lam (2011); Beatley (2012); OECD (2014); EC (2017) }\end{array}$ \\
\hline $\begin{array}{l}\text { Green energy supply } \\
\text { and management }\end{array}$ & $\begin{array}{l}\text { Crenshaw (1992); Walter (1992); Newman and Kenworthy (1999); Beatley (2000, 2012); } \\
\text { Devuyst (2001); Roberts et al. (2009); Hammer et al. (2011); Kim et al. (2012); } \\
\text { OECD (2014); Yigitcanlar and Lee (2014); De Jong (2015); EC (2017) }\end{array}$ \\
\hline $\begin{array}{l}\text { 11. Population density and } \\
\text { land management }\end{array}$ & $\begin{array}{l}\text { Newman and Kenworthy (1999); Kahn (2006); Roberts et al. (2009); } \\
\text { OECD (2014); EC (2017) }\end{array}$ \\
\hline $\begin{array}{l}\text { 12. Citizens' } \\
\text { consumption pattern }\end{array}$ & $\begin{array}{l}\text { Newman and Kenworthy (1999); Kahn (2006); Roberts et al. (2009); OECD (2014); } \\
\text { Schoolman, Shriberg, Schwimmer and Tysman (2016) }\end{array}$ \\
\hline $\begin{array}{l}\text { 13. Overall quality of citizens } \\
\text { and education }\end{array}$ & $\begin{array}{l}\text { Newman and Kenworthy (1999); Kahn (2006); Roberts et al. (2009); OECD (2014); } \\
\text { Schoolman et al. (2016) }\end{array}$ \\
\hline $\mathrm{CO}_{2}$ emission as a green city & Kahn (2006); Roberts et al. (2009); EIU (2011); Head and Lam (2011) \\
\hline $\begin{array}{l}\text { 15. Prevention and treatment of } \\
\text { environmentally linked } \\
\text { diseases, and other health } \\
\text { and safety issues }\end{array}$ & $\begin{array}{l}\text { Newman and Kenworthy (1999); Kahn (2006); van Dijk (2011); WHO (2012); } \\
\text { University of Washington (2016) }\end{array}$ \\
\hline Land price & Kahn (2006); Roberts et al. (2009); EC (2017) \\
\hline
\end{tabular}

Although there was much research about bridging green city and place marketing except when urban green spaces were taken as the attributes of a green city brand (e.g., [83-85]), and place attachment was created through an interaction between human and nature locally [27]. Urban attractiveness was an indicator that measures the success of green urban growth [11]. As identified by the Organisation for Economic Co-operation and Development (OECD), six potential areas of green cities, namely energy, land use and transport, housing and buildings, water resource management, solid waste management, and green goods and services, all contribute to a "healthier local environment and urban attractiveness" [86]. These aspects, however, require a progressive use of technological advancement $[18,53,87,88]$ and nature-culture interaction [27] in attempt to an environmentally sustainable form of development [89].

The growth of "smart city" concept is not a separate trajectory but as a natural development, evolution and integration of information and communication technology (ICT) in every aspect of urban development $[5,31]$, and urban sustainability [11,90]. The use of ICT is thus undoubtedly the focus of smart city in its many forms, but soon scholars recognized the conceptualization of smart city to embrace a wider scope of areas such as human and social capital, infrastructure, quality of life, natural resource management, governance and so forth [20]. As a result, a smart city is "an innovative city that uses ICT and other means to improve quality of life, efficiency of urban operation and services, 
and competitiveness, while ensuring that it meets the needs of present and future generations with respect to economic, social and environmental aspects" [51].

The key of a smart city is a movement to an optimization and efficiency of resource use [31,47,91,92] through leadership, inter- and intra-generational interaction and human-technology urban integration [90]. Classical examples included Cohen's [93] six-dimensional "Smart City Wheel" and Dameri's [94] "land-people-infrastructure-government" model, which all provided measurable variables of city smartness. These propositions have indeed emphasized the crucial role of human dimension in smart urban development [90]. The use of ICT is focused on developing urban centers that are at once integrated, habitable and sustainable [95]. Hence, the ability to steer cities to achieve optimization of assets and the clever usage of urban resources are determined by individual citizens, community, enterprises and, collectively, the entire society [5,92]. As a result, the smart city initiative was also collected, realized and studied in a number of dimensions [51,90,93,96-101], as provided in Table 2.

Table 2. Aspects of smart city research and discussions.

\begin{tabular}{|c|c|}
\hline Smart Dimension & $\begin{array}{l}\text { Smart City Aspect (Dimensions of Smart City by IESE Center for } \\
\text { Globalization and Strategy, 2017; [102]) }\end{array}$ \\
\hline - $\quad$ (A smart economy) & \\
\hline $\begin{array}{l}\text { - The overall economic development is } \\
\text { based on a smart-city initiative }\end{array}$ & $\begin{array}{ll}\text { 1. } & \text { Smart city leads overall economic development } \\
\text { (economy; international outreach) } \\
\text { 2. } & \text { Standard of living (economy; international outreach) } \\
\text { 3. } & \text { Employment opportunities (economy; human capital) } \\
\text { 4. } & \text { Smart development of manufacturing sectors (economy) }\end{array}$ \\
\hline - $\quad$ Land (A smart environment) & \\
\hline $\begin{array}{l}\text { - The importance of the environment for } \\
\text { the quality of life in the urban space }\end{array}$ & $\begin{array}{ll}\text { 5. } & \text { Quality of life (environment) } \\
\text { 6. } & \text { Urban environmental quality (environment) }\end{array}$ \\
\hline $\begin{array}{l}\text { - The } \mathrm{CO}_{2} \text { emission reduction like the } \\
\text { main goal of the smart city }\end{array}$ & 7. $\mathrm{CO}_{2}$ emission as a smart city (environment) \\
\hline - $\quad$ People (Smart people) & \\
\hline $\begin{array}{l}\text { - Citizens seen like targets for the } \\
\text { smart initiatives }\end{array}$ & $\begin{array}{l}\text { 8. Attitudes of citizens towards smart city (human capital; social cohesion) } \\
\text { 9. Quality of individual citizens (human capital) }\end{array}$ \\
\hline $\begin{array}{l}\text { - Subjects involved are local and central } \\
\text { governments, universities, businesses }\end{array}$ & $\begin{array}{l}\text { 10. Education opportunities for citizens (human capital) } \\
\text { 11. Quality of local communities (social cohesion) } \\
\text { 12. Quality of government (governance) } \\
\text { 13. Quality of universities (human capital) } \\
\text { 14. Quality of business sector (human capital) }\end{array}$ \\
\hline - $\quad$ Infrastructure (Smart living) & \\
\hline - $\quad$ Better use of energy & 15. Energy use efficiency in the city (technology) \\
\hline - $\quad$ Renewal energy source & 16. Use of renewable energy (technology) \\
\hline - $\quad$ Buildings efficiency & 17. Energy use efficiency of buildings (technology) \\
\hline $\begin{array}{l}\text { Efficient services (e.g., transport) } \\
\text { (Smart mobility) }\end{array}$ & $\begin{array}{l}\text { 18. Internet and telecommunication connection (technology) } \\
\text { 19. General condition of residence (environment; public administration) } \\
\text { 20. Smart transport services (mobility and transportation) } \\
\text { 21. Water supply (public administration) }\end{array}$ \\
\hline - $\quad$ Government (Smart governance) & \\
\hline $\begin{array}{l}\text { - Defines the rules and priorities for } \\
\text { smart initiatives }\end{array}$ & 22. Overall city governance towards a smart city (governance) \\
\hline - $\quad$ Is itself the owner of smart processes & 23. Government as smart city initiator (urban planning) \\
\hline $\begin{array}{l}\text { - Gains efficiency and effectiveness in } \\
\text { delivering smarter public services }\end{array}$ & $\begin{array}{l}\text { 24. Provision of public services (public administration) } \\
\text { 25. Public and private medical care (public administration) }\end{array}$ \\
\hline $\begin{array}{l}\text { - Gains consensus thanks to the better } \\
\text { quality of life }\end{array}$ & $\begin{array}{l}\text { 26. Consensus among stakeholders (governance; international outreach) } \\
\text { 27. Social welfare (public administration) } \\
\text { 28. Physical safety (public administration) }\end{array}$ \\
\hline
\end{tabular}


The idea and advocacy of smart city and smart urbanism did not free from criticism. There have been vigorous discussions and debates on, for example, the lack of knowledge basis but technology-driven smart development [103], the contrasting geographies of smartness across different locations and settings [104], as well as the problem of one-size fits all narratives of smartness [105]. It is therefore the primary aim of this study to observe and empirically investigate the knowledge-perception gap of smart (and green) city attributes by a local case.

\subsection{Green-Smart Integration}

There is a quest for understanding smart city in the context of urban sustainability [6], especially when cities nowadays are the keys for defining "why and how the urban condition affects out common future" [34]. Angelidou [15] identified four areas requiring comparative studies between: (1) national and local strategies of urban development; (2) urban development stages of new and existing cities; (3) hard and soft infrastructure oriented strategies [33,43,50,106]; and (4) economic sector-based and geographically based reference areas. Caragliu [20] suggested six important criteria for building a smart city, which indicated that it does not rely only on the persuasive use of ICT but on an all-round consideration of urban sustainability. Nijkamp [107] also summarized the common characteristics of a smart city that had reiterated in many previous findings, where multi- and inter-disciplinary criteria were clear presented and considered.

All these smart city proponents have made clear dispositions that there should not be a discrete and rigid form of city theme. Apart from the examples of empirical evidence shown earlier, more green-smart overlapping is found across the literature (Table 3). The earlier descriptions of the city themes have implied: firstly, a multi-dimensional essence of each theme represented by several attributes; and, secondly, the presence of some common factors, e.g., people/human, institutional/governance and hard/soft infrastructure. This shows that the success of a theme in each city may be determined and assessed through more than one set of attributes from a specific theme, but more environmental indicators are necessary [6].

Table 3. Examples of overlapping ideas in green and smart city initiatives.

\begin{tabular}{llc}
\hline $\begin{array}{l}\text { Areas of Green- } \\
\text { Smart Overlapping }\end{array}$ & Descriptions & Source \\
\hline $\begin{array}{l}\text { Parks and green } \\
\text { spaces, and green } \\
\text { infrastructure }\end{array}$ & $\bullet \quad \begin{array}{l}\text { Green spaces as an important dimension of smartness. } \\
\text { Smart city initiatives rely on a more developed } \\
\text { infrastructure than polluted cities with limited green areas. }\end{array}$ & Neirotti et al., 2014 [92] \\
\hline ICT & $\begin{array}{l}\text { Smart city encompasses different socio-environmental aspects } \\
\text { and ICT applications. }\end{array}$ & Shaw, 2013 [62] \\
\hline $\begin{array}{l}\text { Economic } \\
\text { development }\end{array}$ & $\begin{array}{l}\text { Smart city is an engine of economic opportunity, e.g., the case of of } \\
\text { Vancouver to improve its "green city" brand. }\end{array}$ & Rosol, 2013 [62] \\
\hline $\begin{array}{l}\text { Multi-dimensional } \\
\text { integration and } \\
\text { sustainability }\end{array}$ & $\begin{array}{l}\text { Smart city shares or integrates elements from both creative } \\
\text { industries and environmental sustainability. }\end{array}$ & Deakin, 2014 [90] \\
\hline $\begin{array}{l}\text { Multi-dimensional } \\
\text { integration and } \\
\text { sustainability }\end{array}$ & $\begin{array}{l}\text { The overarching conceptualization of sustainable development, } \\
\text { ecological modernization, and regenerative sustainability } \\
\text { implies a major overlap in various city categories. }\end{array}$ & De Jong et al., 2015 [31] \\
\hline
\end{tabular}

In Hong Kong, the government has led the urban development through a number of policy agendas and planning studies such as Policy Addresses. These documents represent the most important and the highest-level policy direction each year delivered by the Chief Executive (the leader of Hong Kong) that every public sector authority must be committed to follow and take actions. Between the decade of 2006 and 2017, for example, the Policy Addresses guided the public sector to move towards the green city development at least twice (2005-2006 and 2007-2008). The high-level policy agenda of smart city appeared in 2011-2012 for "pursuing key initiatives under the Digital 21 Strategy". 
In recent years, the term of "smart city" has been reiterated in the three Policy Addresses of 2015 to 2017. Although there were public consultation exercises in most of the urban development and planning initiatives, there is no common platform that allows relevant stakeholders or the general public to share views on green city and smart city conceptual and practical integration in the society. There is also lack of combined study on citizens' understanding and interpretation of these concepts. This might have caused the problem of shifting paths or multi-nuclei thematization strategies over the years.

Following the policy directions, the Hong Kong government has taken effective actions to enhance the environmental sustainability of the city. Bureaus and departments identified a list of policy and action areas, including air quality, business and environmental protection, energy efficiency and conservation, environmental assessment and planning, global environment, nature conservation, noise, public participation, sustainable development, waste and recycling, and water quality [108]. Regarding smart city development, the government also conducted a consultant research, and formulated a blueprint and a set of action plans under the six dimensions of Smart City Wheel [109]. These smart initiatives even link closely with the current city brand of Hong Kong $[110,111]$ although green and smart development plans appear to implement in separate trajectories.

\section{Methods}

This study used survey as the data collection method [112]. The survey, which targeted Hong Kong local residents, was conducted between February and April 2016. The research only covered local residents who held a Hong Kong Identity Card at the time of the survey and who have resided in the city for at least one year. Temporary residents and tourists were excluded. Interviews were conducted during daytime both on weekdays, weekends, and public holidays to maximize the extent of locating a more diversified combination of residents.

The sampled locations included six different districts in Hong Kong. These districts, as indicated in Figure 1, are located in both urban residential areas (Central and Western District, Kwun Tong, Sham Shui Po and Yau Tsim Mong) and new towns sites (Shatin and Yuen Long). Some of these districts are characterized by their roles and histories in Hong Kong, for example, Central and Western District is the central business district with more affluent groups of populations; Kwun Tong, Yuen Long and Sham Shui Po have a relatively large percentage of ethnic minorities and new immigrants; Yau Tsim Mong is the core urbanized area; and Shatin is the first and the largest new town in the territory.

Interviewers were trained to perform cluster random sampling in locations of the sampled districts (e.g., near shopping areas, main residential estates and transport nodes). Cluster random sampling was used because the samples in each location are considered heterogeneous in nature. Finally, the survey distributed 300 questionnaires at all six locations, while 243 completed responses were collected, which constituted a response rate of $81 \%$. The distribution of number of collected questionnaires in each district included: Central and Western District (40), Kwun Tong (42), Sham Shui Po (42), Yau Tsim Mong (39), Shatin (37) and Yuen Long (43).

The variables measured were a list of 7-point Likert statements on the green city and smart city attributes, as shown in Tables 1 and 2, randomly allocated on the questionnaire. These statements were provided bilingually (in English and Chinese) in a questionnaire. Their scale ranged from 1 (strongly disagree) to 7 (strongly agree). Each respondent was given a prescribed definition of green city and smart city before starting the questionnaire, whereas those who claimed that they did not have any idea about these two city themes would not participate in the survey. The respondents were requested to rate the statement according to their perceived level of performance in each attribute, and answer the questions based on their "feeling and experience in Hong Kong", which implied that they could provide ratings regardless of their length of residence. Nonetheless, the respondents were allowed to skip statements for which they did not have any knowledge or feeling. Finally, demographic and socio-economic characteristics including gender, age, educational level, working status and years of residence were also collected. 


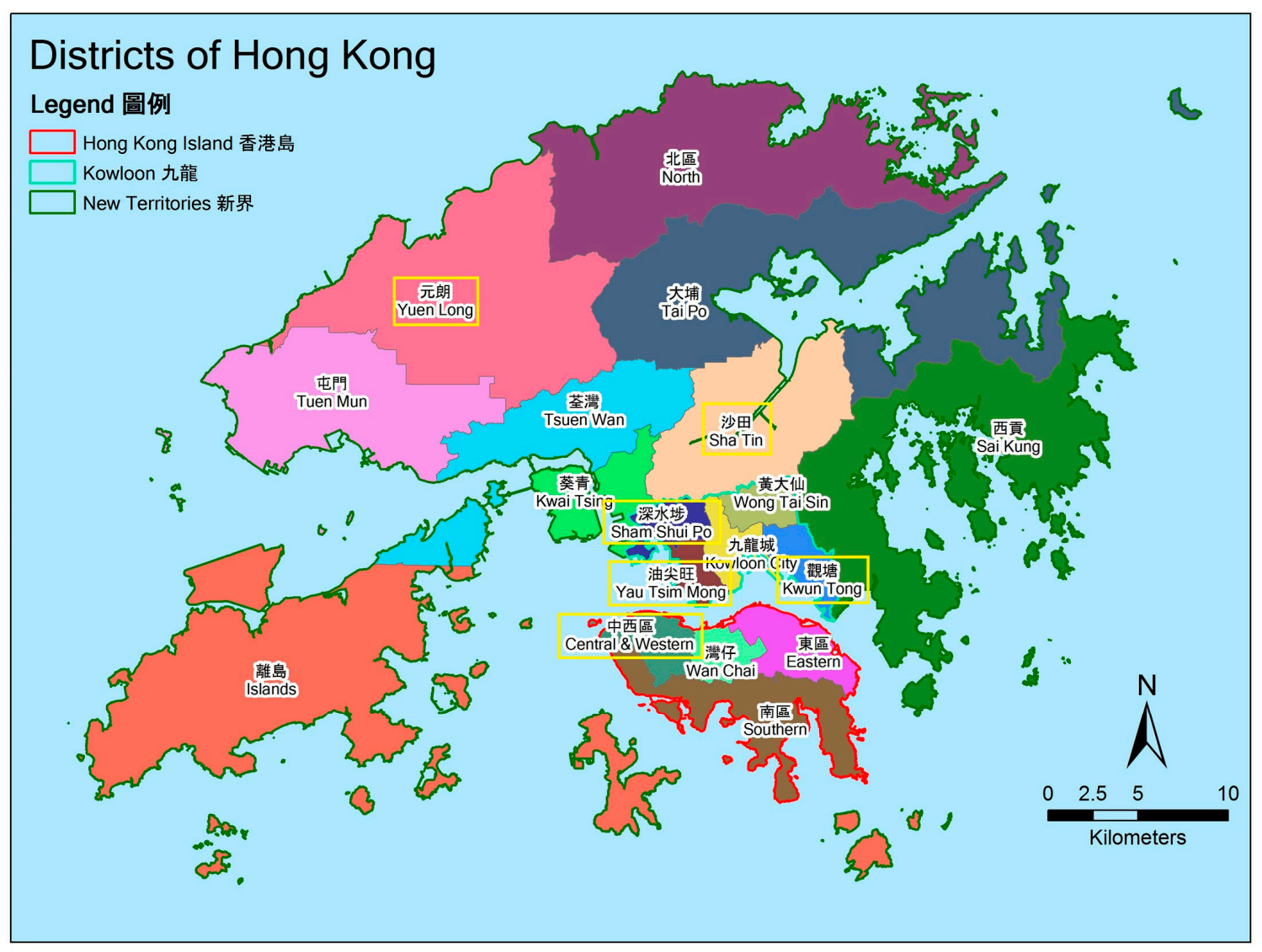

Figure 1. Locations of the districts in the survey.

This study identifies the factors in a combined green-smart city theme of Hong Kong as associated by local residents. Due to the absence of both a guiding theory and an unambiguous structure for a green-smart city, explanatory factor analysis was deemed an appropriate method by which to identify the specific variable structure $[25,113]$. This study used the Principal Axis Factoring method [114] to avoid the normality assumption [115], as well as a varimax rotation to maximize the variance of the squared loadings of a factor and to produce a clear classification for the purpose of interpretation [116]. Following the Kaiser-Guttman rule, the analysis extracted factors with eigenvalues greater than one, considered elements with a loading $>0.5$ [117] and eliminated those attributes that have more than one factor with a $>0.4$ factor loading [118].

The analysis further identifies the relationships between performance of green-smart city attributes and the perception of success of the city themes. Linear regression is the principal method to find out the model structure and its underlying significant factors leading to a locally-perceived successful green or smart city respectively.

\section{Results}

The respondents' socio-demographic profile is shown in Table 4. They have an almost even gender distribution, a majority of age group between 20 and 49 (over 80\%), a high qualification profile (about half having education level of university or above), mainly employees and students (having a sum of over $80 \%$ ), and a monthly personal income of below $\mathrm{HK} \$ 20,000$ (equivalent to about US\$2560). The range of duration of respondent stays is between 1 and 70 years in Hong Kong with a higher percentage of 30-39 years. 
Table 4. Characteristics of respondents $(n=243)$.

\begin{tabular}{|c|c|c|c|}
\hline \multicolumn{2}{|c|}{ Socio-Demographic Attributes } & \multicolumn{2}{|c|}{ Local Residents } \\
\hline & & Frequency & Percent \\
\hline \multirow{3}{*}{ Gender } & Male & 124 & 51.0 \\
\hline & Female & 119 & 49.0 \\
\hline & Total & 243 & 100.0 \\
\hline \multirow{8}{*}{ Age } & $18-19$ & 15 & 6.2 \\
\hline & $20-29$ & 111 & 45.7 \\
\hline & $30-39$ & 49 & 20.2 \\
\hline & $40-49$ & 38 & 15.6 \\
\hline & $50-59$ & 10 & 4.1 \\
\hline & 60 or above & 7 & 2.9 \\
\hline & Missing & 13 & 5.3 \\
\hline & Total & 243 & 100.0 \\
\hline \multirow{6}{*}{ Educational level } & None or don't know & 0 & 0.0 \\
\hline & Primary or elementary & 2 & 0.8 \\
\hline & Secondary or post-secondary & 91 & 37.4 \\
\hline & University or above & 127 & 52.3 \\
\hline & Missing & 9 & 3.7 \\
\hline & Total & 243 & 100.0 \\
\hline \multirow{8}{*}{ Years of residence } & 1-9 years & 10 & 4.1 \\
\hline & $10-19$ years & 50 & 20.6 \\
\hline & 20-29 years & 95 & 39.1 \\
\hline & 30-39 years & 32 & 13.2 \\
\hline & 40-49 years & 23 & 9.5 \\
\hline & 50 years or above & 8 & 3.3 \\
\hline & Missing & 31 & 1.6 \\
\hline & Total & 243 & 100.0 \\
\hline \multirow{8}{*}{ Working status } & Employed & 108 & 44.4 \\
\hline & Unemployed & 10 & 4.1 \\
\hline & Retired & 8 & 3.3 \\
\hline & Housewife & 18 & 7.4 \\
\hline & Students & 90 & 37.0 \\
\hline & Others & 1 & 0.4 \\
\hline & Missing & 8 & 3.3 \\
\hline & Total & 243 & 100.0 \\
\hline \multirow{8}{*}{ Monthly personal income } & Below HK $\$ 10,000$ & 92 & 37.9 \\
\hline & HK $\$ 10,001-20,000$ & 61 & 25.1 \\
\hline & HK $\$ 20,001-30,000$ & 32 & 13.2 \\
\hline & HK $\$ 30,000-40,000$ & 10 & 4.1 \\
\hline & HK $\$ 40,000-50,000$ & 7 & 2.9 \\
\hline & HK $\$ 50,001$ or above & 7 & 2.9 \\
\hline & Missing & 34 & 14.0 \\
\hline & Total & 243 & 100.0 \\
\hline
\end{tabular}

\subsection{Green-Smart Structure of Hong Kong}

Prior to the operation of factor analysis, the tests for reliability of responses and the appropriateness of factor analysis yielded satisfactory results with Cronbach's alpha of 0.910, the Kaiser-Meyer-Olkin measures of sampling of 0.946, and Bartlett's test of sphericity had significant results for the groups. Based on these results, the Cronbach's alpha value corresponds to a significantly high level of data reliability [119] and an excellent internal consistency along the responses [120]. The data available can also sustain the use of factor analysis as a reliable and confident analytical tool for the research [118,121]. 
The factor analysis extracted seven factors from the entire list of green city and smart city variables as presented in Table 5. These factors are formed according to the nature of the green-smart aspects within each factor. They include three integrated factors of "physical and organic green-smart infrastructure" (denoting both the provision of physical infrastructure and structures related to green-cum-smart city), "governance and livelihood of a smart city" (indicating several basic livelihood-related elements of smart city) and "quality of smart society" (relating the quality of different societal actors in a smart city). Another four single-item factors are water quality, employment opportunities, ICT and transport services of green or smart city, respectively. Overall, the factors represented approximately $64 \%$ of the total variance of the analysis.

Table 5. The results of descriptive scores and factor analysis for adopted items of green and smart city theme in Hong Kong $(n=243)$.

\begin{tabular}{|c|c|c|c|c|}
\hline Factor and Underlying Attributes & Mean & S.D. & Factor Loading & Cumulative $\%$ of Variance \\
\hline Physical and organic green-smart infrastructure & & & & 24.934 \\
\hline Population density and land management & 3.07 & 1.639 & 0.821 & \\
\hline $\mathrm{CO}_{2}$ emission as a green city & 3.46 & 1.353 & 0.814 & \\
\hline Green energy supply and management & 3.52 & 1.322 & 0.813 & \\
\hline Green architecture and buildings & 3.49 & 1.360 & 0.783 & \\
\hline Use of renewable energy in a smart city & 3.44 & 1.373 & 0.760 & \\
\hline Energy use efficiency of buildings in a smart city & 3.52 & 1.256 & 0.752 & \\
\hline Land price of a green city & 2.62 & 1.774 & 0.742 & \\
\hline Overall city governance towards a green city & 3.53 & 1.318 & 0.695 & \\
\hline Waste management & 3.69 & 1.500 & 0.634 & \\
\hline Smart city leads overall economic development & 3.58 & 1.429 & 0.606 & \\
\hline Parks and green spaces & 3.69 & 1.344 & 0.590 & \\
\hline Citizen's consumption pattern in a green city & 3.74 & 1.328 & 0.573 & \\
\hline Food production by urban agriculture & 3.54 & 1.330 & 0.562 & \\
\hline Quality of life in a smart city & 3.99 & 1.432 & 0.541 & \\
\hline Governance and livelihood of a smart city & & & & 36.309 \\
\hline Provision of public services & 4.03 & 1.325 & 0.750 & \\
\hline Government as smart city initiator & 3.60 & 1.461 & 0.718 & \\
\hline Social welfare & 3.92 & 1.381 & 0.652 & \\
\hline Physical safety & 4.73 & 1.379 & 0.501 & \\
\hline Quality of smart society & & & & 47.205 \\
\hline Quality of individual citizens in a smart city & 4.42 & 1.187 & 0.712 & \\
\hline Quality of local communities in a smart city & 4.30 & 1.207 & 0.707 & \\
\hline Quality of universities in a smart city & 4.45 & 1.246 & 0.632 & \\
\hline Education opportunities for citizens & 4.91 & 1.226 & 0.598 & \\
\hline Quality of business sector in a smart city & 4.20 & 1.299 & 0.521 & \\
\hline Water quality of a green city & & & & 52.835 \\
\hline Fresh and sea water quality of a green city & 4.10 & 1.420 & 0.679 & \\
\hline Employment opportunities in a smart city & & & & 56.704 \\
\hline Employment opportunities in a smart city & 4.24 & 1.407 & 0.500 & \\
\hline Information and communication technology in a smart city & & & & 60.348 \\
\hline Internet and telecommunication connection in a smart city & 4.92 & 1.348 & 0.703 & \\
\hline Smart transport services & & & & 63.794 \\
\hline Smart transport services & 4.06 & 1.217 & 0.504 & \\
\hline
\end{tabular}

Cronbach's alpha $=0.910$; Kaiser-Meyer-Olkin $(\mathrm{KMO})$ measures of sampling adequacy $=0.946$; Bartlett's test of sphericity $(p=0.000)$ Extraction method: Principal Axis Factoring. Rotation method: Varimax with Kaiser Normalization. Eigenvalue of each factor $>1$; Factor loading of each element $>0.5$. Attributes loading on more than one factor with a loading score of $\geq 0.4$ on each factor eliminated.

A reconfiguration and partial integration of green-smart city theme attributes can be identified in this empirical case of Hong Kong. This is noticed in the first factor of "physical and organic green-smart infrastructure", where a relatively complex mixture of green and smart attributes appeared in this factor. Some other dimensions are more specific and concise, for example, the two factors related to the citizens' livelihood and societal quality for a successful smart city.

The average levels of locally perceived performance of the green and smart city attributes ranged between 2.62 and 4.92 as shown in Table 5. The item with the highest mean score is "Internet and telecommunication connection in a smart city", followed by "education opportunities for citizens in a smart city" among other smart city attributes. Overall, the mean values of these smart city items 
are relatively higher than those of the green city theme. The lowest item "land price of a green city", which is exceptionally outlying $(m=2.62)$.

\subsection{Local-Perception Models of Successful Green City and Smart City}

The Kurtosis values among the attributes ranged between -0.760 and 0.140 , which are considered acceptable to prove normal univariate distribution $[122,123]$. The satisfactory Cronbach's alpha also gives the way to an assessment of the effects of the green and smart city attributes (independent variables) on the recognition of a successful green or smart city theme for Hong Kong (dependent variable). This dependent variable is measured by two Likert statements on the level of agreeing Hong Kong can become a successful green and smart city. The whole set of green and smart city attributes were then entered into regression models separately to study their respective determinants in the local perception of green or smart city. Multicollinearity is discounted for the analysis because all variance inflation factors are less than three, which is below the critical value [124].

The results of the regression analysis testing the model of green and smart city attributes are presented in Table 6. The overall fit of the models is low with adjusted $R$-Squares of 0.059 (smart city model) and 0.133 (green city model), but considered acceptable with a value of over 0.1 in terms of behavioral studies [125].

Table 6. Models of green city and smart city attributes perceived by inbound visitors and local residents.

\begin{tabular}{lc}
\hline Model & Local Residents $(n=243)$ \\
\hline Believing Hong Kong can become a successful green city [Coefficient $(t$-value)] \\
Constant term & $2.970(5.059)^{* *}$ \\
Population density and land management of a green city & $-0.258(-2.840)^{* *}$ \\
Quality of individual citizens in a smart city & $0.217(2.383)^{*}$ \\
Adjusted $R$-square & $0.059(\mathrm{~F}=5.111)^{* *}$ \\
\hline Believing Hong Kong can become a successful smart city [Coefficient $(t$-value $)]$ \\
Constant term & $1.256(2.017)^{*}$ \\
Quality of local communities in a smart city & $0.343(3.429)^{* *}$ \\
Citizen's consumption pattern in a green city & $0.260(2.918)^{* *}$ \\
Government as smart city initiator & $-0.214(-2.052)^{*}$ \\
Adjusted $R$-square & $0.133(\mathrm{~F}=7.646)^{* *}$ \\
\hline
\end{tabular}

** Correlation is significant at the 0.01 level (2-tailed); * Correlation is significant at the 0.05 level (2-tailed); $t$-values in parentheses (independent variables exhibiting $t$-values $<1.0$ are excluded).

The two models are statistically significant to explain the perceived determinants of a successful green city and smart city. In the green city model, the respondents considered "population density and land management of a green city" and "quality of individual citizens in a smart city" as the significant determinants of Hong Kong as a successful green city. This model has a relatively lower explanatory power in predicting the influential attributes against the success of the theme than the smart model. In this relatively powerful model, three factors, "quality of local communities in a smart city", "citizen's consumption pattern in a green city" and "government as smart city initiator", contribute to a smart Hong Kong.

\section{Discussion}

There are several phenomena regarding the local perception of green city and smart city paradigm based on the findings in the case of Hong Kong. The factor analysis in Table 5 results in two distinguished areas of factors, one green-smart mixture of infrastructure and other specific or single-element factors about greenness or smartness. The regression in Table 6 also reveals cross-theme determinants in both green and smart city models, for example, the quality of smart citizens does influence the perceived success of a green city, whereas green consumption pattern tends to lead 
to a successful smart city. These findings prove some degree of overlapping in green-smart urban development as reflected in the literature $[8,9]$.

The extraction of several single-element factors suggest that local people in Hong Kong tend to perceive several outstanding elements from others. These key elements include overall fresh and sea water quality in a green city; provision of employment opportunities; ICT use; and transport services in a smart city.

From the two regression models, specifically, the negative coefficient indicates that a lower population density and looser urban land management tend to lead Hong Kong to become greener, whereas smarter citizens also help positively. On the contrary, local residents believe that smart local community and public green consumption pattern both positively build up a smarter Hong Kong, while proactive engagement of the government, however, makes the condition less successful. The magnitude of these factors in both green and smart models represents only weak correlation between independent and dependent variables with coefficients ranged between about 0.2 and 0.3 (Table 6). Furthermore, a relatively stronger smart city model than the green city model suggests that local people may have clearer linkage from the attributes of a smart city to its success in Hong Kong.

The less powerful models imply some probable phenomena. Firstly, the models bring about the presence of non-specified factors (e.g., political) in the decision about a successful green or smart city. Multi- and inter-disciplinary criteria may complicate the interpretation of greenness and smartness concepts (see for example, [107]). Secondly, there appears a lack of knowledge or experience about how a successful green or smart city is constituted, and therefore a mixed perception of green-and-smart attributes is the largest factor. Lastly, a weak connection between a successful city theme and its underlying determinants is observed. This may due to an abovementioned knowledge-perception gap of green and smart urban governance across the society $[6,29,30]$.

On the one hand, the respondents believe some of the factors of a successful green-smart city should relate to a specific element such as their livelihood and the quality of different actors in the society, as well as some single factors like water quality, ICT and transport system. This allows a city to specify its clear theme such as green architecture, zero-waste or others in thematizing or branding a city. From the regression, local people associate the performance of limited number of elements with the overall green-smart urban development. This may arguably imply simple perception of successful urban governance on green and smart themes.

On the other hand, however, the first and combined factor of green and smart infrastructure appears to be difficult to achieve such "simplicity". What has evolved during urban development so far points toward a multi-dimensional consideration into urban sustainability. The so-called "simple" perception of, for example, a successful green city, indeed represents "complexity" for decision makers to cope with a narrow or a sectoral perspective to thematize a city as green $[39,43,50,126]$. Nevertheless, the integration of green-smart aspects allows a holistic perspective for sustainable urban development through for example the use of "sustainability indicators" to assess the performance of such development. To conclude, this complexity-simplicity paradox is a matter of value judgment and sometimes, political ecology [117,127]. Decision makers should therefore address this issue through the understanding and the bridging of a knowledge-perception gap of sustainable urban development.

The regression results reveal that local people believe that human factor is the key of success in both green city and smart city initiatives. The models consist of determinants related to different societal actors such as the quality of individuals and local communities, population density and the government as the leader. These findings concur with what scholars have proposed in the literature, for example, the human dimension of smart city development (e.g., $[5,90,92,94,101])$. The proposed green-and-smart combined factors are complement and constructive to model the attributes of sustainable urban development in guiding participatory communities [128]. 


\section{Conclusions}

This paper achieves identifying the factors in a green-smart theme of Hong Kong based on local perception. The findings suggest that local residents believe Hong Kong is performing smarter than greener. A combined structure consists of one mixed green-smart infrastructural elements and six other specific or single-element factors about greenness or smartness is revealed. This dichotomy in the green-smart city theme structure implies a paradoxical phenomenon of how local people consider successful green and smart urban development in a metropolis like Hong Kong.

As argued earlier, the Hong Kong government has had clear policy directions and effective actions to articulate both greenness and smartness in urban development; however, the implementation of each theme is rather siloed in administration across bureaus and departments [101]. Separation of these green and smart initiatives requires a breakthrough to integrate between policies and actions. A stronger connection between some of the green city and smart city initiatives should be brought about to reflect in the exercise of city marketing and branding of Hong Kong, especially when these actions are to be attentive to target new immigrants such as the talented groups.

One area of further study is proposed to adopt quantitative weighting methods for integrating responses, especially those from an expert panel of green, smart and sustainable cities $[59,60,129,130]$. Further comparison may be performed to explicate the disparities among expert-led knowledge, practitioner-led expertise and community-based perceptions for these city themes. Another research possibility is to compare district-based perception by conducted similar regression analysis of Table 6 to identify similarities and differences between locality and perceptions. It is also useful to verify the goodness of patterns across geographical locations.

A major limitation of this paper lies on the low explanatory power of the regression models, which causes weak ability to predict similar conditions in another city. Although the models show only limited explanatory power, especially in the green city aspect, this statistically significant information still draws important conclusions [131] about the relationships and directions between the city attributes and the local perception of a successful city theme as discussed in the last section. The sample contains relatively younger respondents as many of the aged or relatively aged people were unwilling to participate in the survey due to a lengthy questionnaire. This imposes a biased

Another shortcoming of this study is caused by the selection of green and smart themes based on mainly literature discussions and policy agenda in Hong Kong. There are more relevant city themes appeared over the past decades such as eco-city, creative city, digital city, livable city, sustainable city and so forth (e.g., $[34,36,53,54])$. This constraint may indeed become an area for further study on an integration of more themes for a particular city. A "tailor-made" theme of urban development that suits the unique condition of a city is arguably more recognizable, legitimate and sustainable than a single but rigid form of urban development.

Acknowledgments: The research was supported by the Faculty Direct Grant of the Faculty of Social Science at The Chinese University of Hong Kong [Project code: 4052084].

Author Contributions: This study is conducted and administered by Chung-Shing Chan. Lawal M. Marafa is the co-investigator of the study. Lawal M. Marafa has provided comments on the first draft of the paper as well as some of the responses to the reviewers' comments throughout the review process.

Conflicts of Interest: The authors declare no conflict of interest.

\section{References}

1. Firat, A.F.; Ulusoy, E. Why thematization? Adv. Consum. Res. 2009, 36, 777-778.

2. Richards, G.; Wilson, J. Developing creativity in tourist experiences: A solution to the serial reproduction of culture? Tour. Manag. 2006, 27, 1209-1223. [CrossRef]

3. Chu, S.Y. Brand Hong Kong: Asia's World City as method? Vis. Anthropol. 2010, 24, 46-58. [CrossRef]

4. Johnson, R. 'Green City' concept: Proposals for Auckland, New Zealand. Town Plan. Rev. 1984, 55, $290-312$. [CrossRef] 
5. Hollands, R.G. Will the real smart city please stand up? Intelligent, progressive or entrepreneurial? City 2008, 12, 303-320. [CrossRef]

6. Ahvenniemi, H.; Huovila, A.; Pinto-Seppä, I.; Airaksinen, M. What are the differences between sustainable and smart cities? Cities 2017, 60, 234-245. [CrossRef]

7. Lees, D.; Grandmaison, M. Green city. Can. Geogr. 2000, 120, 60.

8. Luvisi, A.; Lorenzini, G. RFID-plants in the smart city: Applications and outlook for urban green management. Urban For. Urban Green. 2014, 13, 630-637. [CrossRef]

9. Ferrara, R. The smart city and the green economy in Europe: A critical approach. Energies 2015, 8, 4724-4734. [CrossRef]

10. Wood, P.; Landry, C. The Intercultural City: Planning for Diversity Advantage; Earthscan: London, UK, 2008; ISBN 978-184-407-436-5.

11. Hall, R.E.; Bowerman, B.; Braverman, J.; Taylor, J.; Todosow, H.; Von Wimmersperg, U. The vision of a smart city. In Paper Presentation, Proceedings of the 2nd International Life Extension Technology Workshop, Paris, France, 28 September 2000; Brookhaven National Lab.: Upton, NY, USA, 2000.

12. Glenn, W.M. Building a clean, green city: ... architects, builders and renovators can minimize waste from a building's design to its demolition. OHS Can. 1993, 9, 24-28.

13. Bright, J. The smart city: Communications utopia or future reality? Telecommunications 1995, 29, $175-181$.

14. Kim, S.A.; Shin, D.; Choe, Y.; Seibert, T.; Walz, S.P. Integrated energy monitoring and visualization system for Smart Green City development: Designing a spatial information integrated energy monitoring model in the context of massive data management on a web based platform. Autom. Construct. 2012, 22, 51-59. [CrossRef]

15. Angelidou, M. Smart city policies: A spatial approach. Cities 2014, 41 (Suppl. 1), S3-S11. [CrossRef]

16. Vojnovic, I. Urban sustainability: Research, politics, policy and practice. Cities 2014, 41 (Suppl. 1), S30-S44. [CrossRef]

17. Busch, H.; Anderberg, S. Green attraction: Transnational municipal climate networks and green city branding. J. Manag. Sustain. 2015, 5, 1-16. [CrossRef]

18. Calzada, I.; Cobo, C. Unplugging: Deconstructing the smart city. J. Urban Technol. 2015, 22, 23-43. [CrossRef]

19. Freytag, T.; Gössling, S.; Mössner, S. Living the green city: Freiburg's Solarsiedlung between narratives and practices of sustainable urban development. Local Environ. 2014, 19, 644-659. [CrossRef]

20. Hatzelhoffer, L.; Humboldt, K.; Lobeck, M.; Wiegandt, C.-C. Smart City in Practice: Converting Innovative Ideas into Reality: Evaluation of the T-City Friedrichshafen; Jovis: Berlin, Germany, 2012; ISBN 978-386-859-151-4.

21. Parkerson, B.; Saunders, J. City branding: Can goods and services branding models be used to brand cities? Place Brand. 2005, 1, 242-264. [CrossRef]

22. Rasoolimanesh, S.M.; Jaafar, M. Residents' perception toward tourism development: A pre-development perspective. J. Place Manag. Dev. 2016, 9, 91-104. [CrossRef]

23. Jim, C.Y.; Chen, W.Y. Perception and attitude of residents toward urban green spaces in Guangzhou (China). Environ. Manag. 2006, 38, 338-349. [CrossRef] [PubMed]

24. Insch, A.; Florek, M. Place satisfaction of city residents: Findings and implications for city branding. In Towards Effective Place Branding Management: Branding European Cities and Regions; Ashworth, G., Kavaratzis, M., Eds.; Edward Elgar Publishing Limited: Cheltenham, UK, 2010; pp. 191-204, ISBN 978-184-844-242-9.

25. Merrilees, B.; Miller, D.; Herington, C. Antecedents of residents' city brand attitudes. J. Bus. Res. 2009, 62, 362-367. [CrossRef]

26. Xu, J.; Hui, C.K.T.; Chan, E.A. Hong Kong's destination image in the eyes of residents. J. China Tour. Res. 2015, 11, 440-460. [CrossRef]

27. Buizer, M.; Elandsb, B.; Vierikko, K. Governing cities reflexively-The biocultural diversity concept as an alternative to ecosystem services. Environ. Sci. Policy 2016, 62, 7-13. [CrossRef]

28. Kavaratzis, M.; Ashworth, G. Hijacking culture: The disconnection between place culture and place brands. Town Plan. Rev. 2015, 86, 155-176. [CrossRef]

29. Gibbs, D.; Jonas, A.E.G. Governance and regulation in local environmental policy: The utility of a regime approach. Geoforum 2000, 31, 299-313. [CrossRef]

30. Raco, M. Sustainable development, rolled-out neoliberalism and sustainable communities. Antipode 2005, 37, 324-347. [CrossRef] 
31. De Jong, M.; Joss, S.; Schraven, D.; Zhan, C.; Weijnen, M. Sustainable-smart-resilient-low carbon-ecoknowledge cities; making sense of a multitude of concepts promoting sustainable urbanization. J. Clean. Prod. 2015, 109, 25-38. [CrossRef]

32. Zenker, S.; Beckmann, S.C. My place is not your place-Different place brand knowledge by different target groups. J. Place Manag. Dev. 2013, 6, 6-17. [CrossRef]

33. Gibbs, D.; Krueger, R.; MacLeod, G. Grappling with smart city policies in an era of market triumphalism. Urban Stud. 2013, 50, 2151-2157. [CrossRef]

34. Parnell, S. Defining a global urban development agenda. World Dev. 2016, 78, 529-540. [CrossRef]

35. Glaeser, E. Triumph of the City: How Our Greatest Invention Makes Us Richer, Smarter, Greener, Healthier, and Happier; Penguin Press: New York, NY, USA, 2011; ISBN 978-159-420-277-3.

36. Low, N.; Gleeson, B.; Green, R.; Radović, D. The Green City: Sustainable Homes, Sustainable Suburbs; UNSW Press: Sydney, Australia, 2005; ISBN 978-041-537-231-2.

37. United Nations Environment Programme (UNEP). Towards a Green Economy: Pathways to Sustainable Development and Poverty Eradication; United Nations Environment Programme (UNEP): New York, NY, USA, 2011. Available online: http://web.unep.org/greeneconomy/resources/green-economy-report (accessed on 1 October 2017).

38. O'Shaughnessy, J.; O'Shaughnessy, N.J. Treating the nation as a brand: Some neglected issues. J. Macromark. 2000, 20, 56-64. [CrossRef]

39. Odero, K.K. New urban spaces: The emergence of green economies. In The Economy of Green Cities: A World Compendium on the Green Urban Economy; Simpson, R., Zimmermann, M., Eds.; Springer: Dordrecht, The Netherlands, 2013; pp. 17-21, ISBN 978-940-071-969-9.

40. Rode, P. Cities and the green economy. In The Economy of Green Cities: A World Compendium on the Green Urban Economy; Simpson, R., Zimmermann, M., Eds.; Springer: Dordrecht, The Netherlands, 2013; pp. 79-98, ISBN 978-940-071-969-9.

41. Baycan, T. Creative cities: Context and perspectives. In Sustainable City and Creativity: Promoting Creative Urban Initiatives; Girard, L.F., Baycan, T., Nijkamp, P., Eds.; Ashgate: Burlington, VT, USA, 2011; pp. 15-53, ISBN 978-140-942-001-9.

42. Hendriksen, B.; Peereboom, E.C. Accelerating green urban growth. In The Economy of Green Cities: A World Compendium on the Green Urban Economy; Simpson, R., Zimmermann, M., Eds.; Springer: Dordrecht, The Netherlands, 2013; pp. 129-148, ISBN 978-940-071-969-9.

43. McKendry, C. Environmental discourse and economic growth in the greening of postindustrial cities. In The Economy of Green Cities: A World Compendium on the Green Urban Economy; Simpson, R., Zimmermann, M., Eds.; Springer: Dordrecht, The Netherlands, 2013; pp. 23-32, ISBN 978-940-071-969-9.

44. World Bank. Eco2 Cities: Ecological Cities as Economic Cities; World Bank: Washington, DC, USA, 2011; Available online: www.worldbank.org/eco2 (accessed on 1 October 2017).

45. Johnson, R. The Green City; Macmillian Co. of Australia: South Melbourne, Australia, 1979; ISBN 978-033-328-940-2.

46. Jonas, A.E.G.; While, A. Greening the entrepreneurial city? Looking for spaces of sustainability politics in the competitive city. In The Sustainable Development Paradox: Urban Political Economy in the United States and Europe; Krueger, R., Gibbs, D., Eds.; Guilford Press: New York, NY, USA, 2007; pp. 123-159.

47. Lindfield, M.; Steinberg, F. Green Cities; Asian Development Bank: Manila, Philippines, 2012.

48. Kahn, M.E. Green Cities: Urban Growth and the Environment; Brookings Institution Press: Washington, DC, USA, 2006; ISBN 978-081-574-816-8.

49. Kearns, P. Learning cities as healthy green cities: Building sustainable opportunity cities. Aust. J. Adult Learn. 2012, 52, 369-391.

50. McKendry, C.; Janos, N. Greening the industrial city: Equity, environment and economic growth in Seattle and Chicago. Int. Environ. Agreem. Politics Law Econ. 2015, 15, 45-60. [CrossRef]

51. International Telecommunication Union (ITU). Smart Sustainable Cities: An Analysis of Definitions; International Telecommunication Union (ITU): Geneva, Switzerland, 2014; Available online: www.itu.int/en/ITU-T/ focusgroups/ssc/.../TR-Definitions.docx (accessed on 1 October 2017).

52. Jabareen, Y. Planning the resilient city: Concepts and strategies for coping with climate change and environmental risk. Cities 2013, 31, 220-229. [CrossRef] 
53. Pickett, S.T.A.; Mcgrath, B.; Cadenasso, M.L.; Felson, A.J. Ecological resilience and resilient cities. Build. Res. Inf. 2014, 42, 143-157. [CrossRef]

54. Wong, T.C.; Yuen, B. Understanding the origins and evolution of eco-city development: An introduction. In Eco-City Planning: Policies, Practice and Design; Wong, T., Yuen, B., Eds.; Springer: Dordrecht, The Netherlands, 2011; pp. 1-14, ISBN 978-940-070-382-7.

55. Kenworthy, J.R. The eco-city: Ten key transport and planning dimensions for sustainable city development. Environ. Urban. 2006, 18, 67-85. [CrossRef]

56. Roumboutsos, A.; Kapros, S.; Vanelslander, T. Green city logistics: Systems of Innovation to assess the potential of E-vehicles. Res. Transp. Bus. Manag. 2014, 11, 43-52. [CrossRef]

57. Rehan, R.M. The phonic identity of the city urban soundscape for sustainable spaces. HBRC J. 2016, 12, 337-349. [CrossRef]

58. Schoolman, E.D.; Shriberg, M.; Schwimmer, S.; Tysman, M. Green cities and ivory towers: How do higher education sustainability initiatives shape millennials' consumption practices? J. Environ. Stud. Sci. 2016, 6, 490-502. [CrossRef]

59. De Jong, M.; Wang, D.; Yu, C. Exploring the relevance of the eco-city concept in China: The case of Shenzhen Sino-Dutch low carbon city. J. Urban Technol. 2013, 20, 95-113. [CrossRef]

60. Meijering, J.V.; Kern, K.; Tobi, H. Identifying the methodological characteristics of European green city rankings. Ecol. Indic. 2014, 43, 132-142. [CrossRef]

61. Yigitcanlar, T.; Lee, S.H. Korean ubiquitous-eco-city: A smart-sustainable urban form or a branding hoax? Technol. Forecast. Soc. Chang. 2014, 89, 100-114. [CrossRef]

62. Shaw, K. Docklands dreamings: Illusions of sustainability in the Melbourne docks redevelopment. Urban Stud. 2013, 50, 2158-2177. [CrossRef]

63. Rosol, M. Vancouver's “EcoDensity" planning initiatives: A struggle over hegemony? Urban Stud. 2013, 50, 2238-2255. [CrossRef]

64. Newman, P.; Kenworthy, J. Sustainability and Cities: Overcoming Automobile Dependence; Island Press: Washington, DC, USA, 1999; ISBN 1559636602.

65. Roberts, P.; Ravetz, J.; George, C. Environment and the City; Routledge: London, UK; New York, NY, USA, 2009.

66. The Economist Intelligence Unit (EIU). Asian Green City Index; Siemens AG: Munich, Germany, 2011.

67. White, T. Green cities: An overview. In Green Cities; Lankford, R.D., Ed.; Greenhaven Press/Gale, Cengage Learning: Farmington Hills, MI, USA, 2011; pp. 11-18.

68. Beatley, T. Green Urbanism: Learning from European Cities; Island Press: Washington, DC, USA, 2000; ISBN 1559636823.

69. Beatley, T. Green Cities of Europe; Island Press: London, UK; Washington, DC, USA; Covelo, CA, USA, 2012.

70. Roley, B. Home and community water management. In Sustainable Cities: Concepts and Strategies for Eco-City Development; Walter, B., Arkin, L., Crenshaw, R., Eds.; EHM Eco-Home Media: Los Angeles, CA, USA, 1992; pp. 101-112, ISBN 0963351109.

71. Head, P.; Lam, D. How cities can enter the ecological age. In Eco-City Planning: Policies, Practice and Design; Wong, T.-C., Yuen, B., Eds.; Springer: Dordrecht, The Netherlands, 2011; pp. 17-30, ISBN 978-940-070-382-7.

72. Siembab, W.; Walter, B. A Telecommunications strategy for sustainable cities. In Sustainable Cities: Concepts and Strategies for Eco-City Development; Walter, B., Arkin, L., Crenshaw, R., Eds.; EHM Eco-Home Media: Los Angeles, CA, USA, 1992; pp. 204-206, ISBN 0963351109.

73. Snyder, R. The role of bicycles in ecological cities. in Sustainable Cities: Concepts and Strategies for Eco-City Development; Walter, B., Arkin, L., Crenshaw, R., Eds.; EHM Eco-Home Media: Los Angeles, CA, USA, 1992; pp. 178-180, ISBN 0963351109.

74. Woodhill, J. How alternative forms of development can reduce traffic congestion. In Sustainable Cities: Concepts and Strategies for Eco-City Development; Walter, B., Arkin, L., Crenshaw, R., Eds.; EHM Eco-Home Media: Los Angeles, CA, USA, 1992; pp. 167-177, ISBN 0963351109.

75. Devuyst, D. Sustainability assessment at the local level. In How Green Is the City? Sustainability Assessment and the Management of Urban Environments; Devuyst, D., Hens, L., de Lannoy, W., Eds.; Columbia University Press: New York, NY, USA, 2001; pp. 175-206, ISBN 978-023-111-803-3.

76. Roseland, M. The eco-city approach to sustainable development in urban areas. In How Green Is the City? Sustainability Assessment and the Management of Urban Environments; Devuyst, D., Hens, L., De Lannoy, W., Eds.; Columbia University Press: New York, NY, USA, 2001; pp. 85-103, ISBN 978-023-111-803-3. 
77. Lehmann, S. Green urbanism: Holistic pathways to the rejuvenation of mature housing estates in Singapore. In Eco-City Planning: Policies, Practice and Design; Wong, T., Yuen, B., Eds.; Springer: Dordrecht, The Netherlands, 2011; pp. 151-179, ISBN 978-940-070-382-7.

78. Lipkis, A. Urban forests: The lifeblood of an eco-city. In Sustainable Cities: Concepts and Strategies for Eco-City Development; Walter, B., Arkin, L., Crenshaw, R., Eds.; EHM Eco-Home Media: Los Angeles, CA, USA, 1992; pp. 128-132, ISBN 0963351109.

79. Newman, P. Resilient infrastructure cities. In Developing Living Cities: From Analysis to Action; Kallidaikurichi, S., Yuen, B., Eds.; World Scientific Pub: Singapore, 2010; pp. 77-106, ISBN 978-981-430-449-8.

80. Walter, B. Sustainable energy overview. In Sustainable Cities: Concepts and Strategies for Eco-City Development; Walter, B., Arkin, L., Crenshaw, R., Eds.; EHM Eco-Home Media: Los Angeles, CA, USA, 1992; pp. 190-203, ISBN 0963351109.

81. Van Dijk, M.P. Three ecological cities, examples of different approaches in Asia and Europe. In Eco-City Planning: Policies, Practice and Design; Wong, T.-C., Yuen, B., Eds.; Springer: Dordrecht, The Netherlands, 2011; pp. 31-50, ISBN 978-940-070-382-7.

82. Hammer, S.; Kamal-Chaoui, L.; Robert, A.; Plouin, M. Cities and Green Growth: A Conceptual Framework. OECD Regional Development Working Papers 2011/08. Available online: http:/ /www.oecd-ilibrary.org/ governance/cities-and-green-growth_5kg0tflmzx34-en (accessed on 1 October 2017).

83. Chan, C.S.; Peters, M.; Marafa, L.M. Public parks in city branding: Perceptions of visitors vis-à-vis residents in Hong Kong. Urban For. Urban Green. 2015, 14, 1157-1165. [CrossRef]

84. Chan, C.S.; Marafa, L.M. The Green branding of Hong Kong: Visitors' and residents' perceptions. J. Place Manag. Dev. 2016, 9, 289-312. [CrossRef]

85. Chan, C.S.; Marafa, L.M. How a green city brand determines the willingness to stay in a city? The case of Hong Kong. J. Travel Tour. Market. 2016, 34, 719-731. [CrossRef]

86. The Organization of Economic Cooperation and Development (OECD). Urban Green Growth in Dynamic Asia: A Conceptual Framework; OECD Publishing: Paris, France, 2014. Available online: www.oecd.org/regional/ regional-policy/Urban-GG-Dynamic-Asia-report.pdf (accessed on 1 October 2017).

87. Crenshaw, R. Minimizing mechanical heating and cooling. In Sustainable Cities: Concepts and Strategies for Eco-City Development; Walter, B., Arkin, L., Crenshaw, R., Eds.; EHM Eco-Home Media: Los Angeles, CA, 1992; pp. 90-98, ISBN 0963351109.

88. European Commission (EC). Evaluation Process; European Commission (EC): Brussels, Belgium, 2017. Available online: http://ec.europa.eu/environment/europeangreencapital/applying-for-the-award/ evaluation-process / (accessed on 1 October 2017).

89. Chambers, P.; Walters, A. Auckland Council: Creating a transformational shift towards a sustainable eco-economy. In The Economy of Green Cities: A World Compendium on the Green Urban Economy; Simpson, R., Zimmermann, M., Eds.; Springer: Dordrecht, The Netherlands, 2013; pp. 381-390, ISBN 978-940-071-969-9.

90. Deakin, M. Smart Cities: Governing, Modelling and Analysing the Transition; Routledge: Abingdon, UK, 2014; ISBN 978-041-565-819-5.

91. Kramersa, A.; Höjera, M.; Lövehagenb, N.; Wangel, J. Smart sustainable cities-Exploring ICT solutions for reduced energy use in cities. Environ. Model. Softw. 2014, 56, 52-62. [CrossRef]

92. Neirotti, P.; de Marco, A.; Cagliano, A.C.; Mangano, G.; Scorrano, F. Current trends in smart city initiatives: Some stylised facts. Cities 2014, 38, 25-36. [CrossRef]

93. Cohen, B. The Smartest Cities in the World 2015: Methodology. Available online: http:/ /www.fastcoexist. com/3038818/the-smartest-cities-in-the-world-2015-methodology (accessed on 1 October 2017).

94. Dameri, R.P. Comparing smart and digital city: Initiatives and strategies in Amsterdam and Genoa. Are they digital and/or smart? In Smart City: How to Create Public and Economic Value with High Technology in Urban Space; Dameri, R.P., Rosenthal-Sabroux, C., Eds.; Springer International Publishing: Cham, Switzerland, 2014; pp. 45-88, ISBN 978-331-906-160-3.

95. Barrionuevo, J.M.; Berrone, P.; Ricart, J.E. Smart cities, sustainable progress. IESE Insight 2012, 14, 50-57. [CrossRef]

96. Qin, H.; Li, H.; Zhao, X. Development status of domestic and foreign smart city. Glob. Presence 2010, 9, 50-52.

97. Coca-Stefaniak, J.A. Place branding and city centre management: Exploring international parallels in research and practice. J. Urban Regen. Renew. 2014, 7, 363-369. 
98. Coca-Stefaniak, J.A.; Carroll, S. Traditional or experiential places?-Exploring research needs and practitioner challenges in the management of town centres beyond the economic crisis. J. Urban Regen. Renew. 2015, 9, 38-45.

99. He, Y.; Stojmenovic, I.; Liu, Y.; Gu, Y. Smart city. Int. J. Distrib. Sens. Netw. 2014. [CrossRef]

100. Dameri, R.P.; Rosenthal-Sabroux, C. Smart City: How to Create Public and Economic Value with High Technology in Urban Space; Springer International Publishing: Cham, Switzerland, 2014; ISBN 978-331-906-160-3.

101. Cheng, I. What Is a "Smart City"? 2015. Available online: http:/ /www.legco.gov.hk/research-publications / english/essentials-1415ise08-what-is-a-smart-city.htm (accessed on 1 October 2017).

102. IESE Center for Globalization and Strategy. (2017). IESE Cities in Motion Index. Available online: http: / / www.iese.edu/en/faculty-research/research-centers/cgs/ (accessed on 1 December 2017).

103. McFarlane, C.; Söderström, O. On alternative smart cities: From a technology-intensive to a knowledge-intensive smart urbanism. City 2017, 21, 312-328. [CrossRef]

104. Luque-Ayala, A.; Marvin, S. Developing a critical understanding of smart urbanism? Urban Stud. 2015, 52, 2105-2116. [CrossRef]

105. Kitchin, R. Marking sense of smart cities: Addressing present shortcomings. Camb. J. Reg. Econ. Soc. 2015, 8, 131-136. [CrossRef]

106. Jarvis, H.; Bonnett, A. Progressive nostalgia in novel living arrangements: A counterpoint to neo-traditional new urbanism? Urban Stud. 2013, 50, 2349-2370. [CrossRef]

107. Nijkamp, P. Smart cities in Europe. In Smart Cities: Governing, Modelling and Analysing the Transition; Deakin, M., Ed.; Routledge: Abingdon, UK, 2014; pp. 173-195, ISBN 978-041-565-819-5.

108. The Hong Kong Special Administrative Region (HKSAR) Government. (2017). Environment. Available online: https: / www.gov.hk/en/residents/environment/air/index.htm (accessed on 1 October 2017).

109. University of Washington. Green Cities and Good Health; University of Washington: Seattle, WA, USA, 2016. Available online: http:/ / depts.washington.edu/hhwb/ (accessed on 1 October 2017).

110. Information Services Department (ISD). HK Developing a Smart City. 2017. Available online: http:/ / www. news.gov.hk/en/record/html/2017/06/20170605_172521.shtml (accessed on 1 October 2017).

111. Office of the Government Chief Information Officer. Report of Consultancy Study on Smart City Blueprint for Hong Kong. 2017. Available online: https:/ / www.smartcity.gov.hk/report/ (accessed on 1 December 2017).

112. Vaske, J.J. Survey Research and Analysis: Applications in Parks, Recreation, and Human Dimensions; Venture Publishing Incorporation: State College, PA, USA, 2008; ISBN 978-189-213-279-6.

113. Xiao, H.; Smith, S.L.J. Case studies in tourism research: A state-of-the-art analysis. Tour. Manag. 2006, 27, 738-749. [CrossRef]

114. Sparks, B. Planning a wine tourism vacation? Factors that help to predict tourist behavioural intentions. Tour. Manag. 2007, 28, 1180-1192. [CrossRef]

115. Fabrigar, L.R.; Wegener, D.T.; MacCallum, R.C.; Strahan, E.J. Evaluating the use of exploratory factor analysis in psychological research. Psychol. Methods 1999, 4, 272-299. [CrossRef]

116. Beerli, A.; Martin, J.D. Factors influencing destination image. Ann. Tour. Res. 2004, 31, 657-681. [CrossRef]

117. Heynen, N. Urban political ecology I. Prog. Hum. Geogr. 2014, 38, 598-604. [CrossRef]

118. Lee, T.-H.; Crompton, J. Measuring novelty seeking in tourism. Ann. Tour. Res. 1992, 19, 732-751. [CrossRef]

119. Kline, P. The Handbook of Psychological Testing, 2nd ed.; Routledge: London, UK, 2000; ISBN 0415211573.

120. Nunnally, J.C.; Bernstein, I.H. Psychometric Theory, 3rd ed.; McGraw-Hill: New York, NY, USA, 1994; ISBN 007047849X.

121. Kaiser, H.F. An index of factorial simplicity. Psychometrika 1974, 39, 31-36. [CrossRef]

122. Trochim, W.M.; Donnelly, J.P. The Research Methods Knowledge Base, 3rd ed.; Atomic Dog: Cincinnati, OH, USA, 2006.

123. Gravetter, F.; Wallnau, L. Essentials of Statistics for the Behavioral Sciences, 8th ed.; Wadsworth: Belmont, CA, USA, 2014; ISBN 978-113-395-657-0.

124. Fox, J. Applied Regression Analysis, Linear Models, and Related Models; Sage Publications: Thousand Oaks, CA, USA, 1997; ISBN 080394540X.

125. Hair, J.; Sarstedt, M.; Hopkins, L.; Kuppelwieser, V. Partial least squares structural equation modeling (PLS-SEM): An emerging tool in business research. Eur. Bus. Rev. 2014, 26, 106-121. [CrossRef]

126. Hills, P.; Welford, R. Ecological modernisation as a weak form of sustainable development in Hong Kong. Int. J. Sustain. Dev. World Ecol. 2002, 9, 315-331. [CrossRef] 
127. Angelo, H.; Wachsmuth, D. Urbanizing urban political ecology: A critique of methodological cityism. Int. J. Urban Reg. Res. 2015, 39, 16-27. [CrossRef]

128. United Nations Development Programme (UNDP). Sustainable Development Goals: Goals 11: Sustainable Cities and Communities; United Nations Development Programme (UNDP): New York, NY, USA, 2016. Available online: http:/ /www.undp.org/content/undp/en/home/sustainable-development-goals/goal11-sustainable-cities-and-communities.html (accessed on 1 October 2017).

129. Diaz-Sarachaga, J.M.; Jato-Espino, D.; Castro-Fresno, D. Application of the Sustainable Infrastructure Rating System for Developing Countries (SIRSDEC) to a case study. Environ. Sci. Policy 2017, 69, 73-80. [CrossRef]

130. Diaz-Sarachaga, J.M.; Jato-Espino, D.; Castro-Fresno, D. Methodology for the development of a new Sustainable Infrastructure Rating System for Developing Countries (SIRSDEC). Environ. Sci. Policy 2017, 69, 65-72. [CrossRef]

131. Abelson, R.P. Statistics as Principled Argument; L. Erlbaum Associates: Hillsdale, NJ, USA, 1995; ISBN 0805805273.

(C) 2018 by the authors. Licensee MDPI, Basel, Switzerland. This article is an open access article distributed under the terms and conditions of the Creative Commons Attribution (CC BY) license (http:/ / creativecommons.org/licenses/by/4.0/). 